Volume 12 Number 3, July-September 2018: pp. 234 - 242. Copyright (c) 2018 FIAT JUSTISIA. Faculty of Law, Lampung University, Bandarlampung, Lampung, Indonesia. ISSN: 1978-5186 | e-ISSN: 2477-6238.

Fiat Justisia is licensed under a Creative Commons Attribution 4.0 International License, which permits unrestricted use, distribution, and reproduction in any medium, provided the original work is

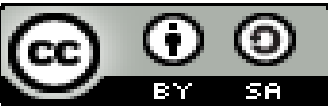
properly cited

\title{
Law Enforcement to Copyright Infringement of Songs on the Internet Media
}

\author{
Andrew Shandy Utama \\ Faculty of Law, Lancang Kuning University, Indonesia \\ andrew.fh.unilak@gmail.com
}

\begin{abstract}
Initially, the scope of Copyright protection only focuses on creative works that are manifested in real terms. The development and advancement of technology make the scope of Copyright protection experience an expansion not only in copyrighted works that are realized in a real form but also protect copyrighted works that are digitized on internet media. The problem discussed in this research is how law enforcement to Copyright infringement of songs on the internet media is? The method used in this research is normative legal research using the regulatory approach. The results of this research indicate that the development and advancement of technology can facilitate the dissemination of songs in MP3 format uploaded on internet media. To prevent the occurrence Copyright infringement of songs on the internet media, in Law Number 28 of 2014 has been stipulated strict criminal sanctions for anyone without permission who has violated the Copyright, especially the economic rights of the owner.
\end{abstract}

Keywords: Copyright, Internet Media, Law Enforcement

How to cite: Andrew Shandy Utama, "Law Enforcement to Copyright Infringement of Songs on the Internet Media", Fiat Justisia, 12 (3), (2018).

DOI: https://doi.org/10.25041/fiatjustisia.v12no3.1211

\section{A. Introduction}

One of the issues that surfaced in the era of free trade was in the field of Intellectual Property Rights. Intellectual Property Rights appear to be a new problem in the context of international trade today. This problem arises because Intellectual Property Rights is one of the fields that is inseparable 
from the agreement package for the establishment of a world trade organization, namely the World Trade Organization (WTO). Efforts to formulate the concept of Intellectual Property Rights are often carried out, both by the government and international organizations. The concept of Intellectual Property Rights itself continues to experience development along with the development of science and technology so that with these conditions, Intellectual Property Rights develop dynamically.

Intellectual Property Rights are rights derived from human works, intentions, and inventions because they are born from human intellectual abilities, and are the result of creative activities of a human's ability to think which is expressed to the public in its various forms, which have benefits to support human life and have value economy. The most important essence of each section of Intellectual Property Rights is the existence of a particular creation. The real form of creation can be in the form of technology, science, art, and literature. The rapid development of life in the economic field, both at the national and international levels, elevate drastically the provision of effective legal protection for Intellectual Property Rights, especially Copyright. Those need further enhanced to create a better atmosphere for the growth and development of the spirit of creation in the fields of science, art, and literature. It is very necessary for the implementation of national development which aims to create a just, prosperous, advanced and independent Indonesian society.

Copyright is intellectual property in the field of science, art, and literature which has a strategic role in supporting the development of the nation and advancing public welfare as mandated by the 1945 Constitution of the Republic of Indonesia. Copyright law development in Indonesia has undergone a long process since the Dutch colonial era to the development of the global economy at present. Many things have been refined from the Copyright law in Indonesia. The refinement is intended as a form of response to Copyright law which always develops parallel with the development of science and technology.

Copyright law discusses the protection of copyrighted works in the fields of science, art, and literature whose nature has been manifested in a real and has an element of originality. Meanwhile, the realization of the work at present is not only manifested in conventional media that can be seen and touched in real terms but can also be expressed through digital media, namely the internet. However, existing Copyright law has problems in protecting copyrighted works in the fields of science, art, and literature expressed on the internet. $^{1}$

\footnotetext{
${ }^{1}$ Budi Agus Riswandi, Copyright on the Internet; Legal Aspects and Problems in Indonesia, Yogyakarta: FH UII Press, (2009), pp. 53-54.
} 
Some cases of Copyright violations that have occurred before include the following:

1. A British music group called Oasis demanded that hundreds of sites on the internet media without permission have video clips of their songs accompanied by the lyrics.

2. The Australian Mechanical Copyright Owners Society (AMCOS) and The Australian Music Publishers Association Ltd stopped a site on internet media that without permission has a list of 40 popular songs since 1989.

3. Wixen Music Publishing demanded that a digital music company from Sweden named Spotify without permission have aired famous songs by Tom Petty, Neil Young, and The Doors.

From the background of the problem described above, the problem that will be discussed in this research is how law enforcement to Copyright infringement of songs on the internet media is?

\section{B. Method}

According to Soerjono Soekanto, legal research is a scientific activity that is based on certain methods, systematics, and thoughts which aims to study one or several specific legal symptoms by analyzing them. ${ }^{2}$ The method used in this research is normative legal research using the approach of legislation, namely Law Number 28 of 2014 about Copyright. Peter Mahmud Marzuki explained that normative legal research is a process to find legal rules, legal principles, and legal doctrines to answer the legal issues faced. ${ }^{3}$

Data sources used in this research are secondary data, namely data obtained from legislation, scientific journals, and legal literature. Data collection techniques used in this research are literature studies. The data analysis technique used in this research is qualitative analysis.

\section{Discussion}

\section{Impact of the Internet to Copyright Law}

The internet is the largest computer network in the world. All computers can communicate with each other using the same language, called Internet Protocol (IP). The internet is experiencing rapid development because it can be used in various activities of human life. With these conditions, the internet has become a new environment, which consists of people from different countries, ages and different jobs that are digitally connected. ${ }^{4}$ The internet is a technological revolution in the field of information technology, where there

\footnotetext{
${ }^{2}$ Soerjono Soekanto, Introduction to Legal Research, Jakarta: UI Press, (2007), p. 43.

${ }^{3}$ Peter Mahmud Marzuki, Legal Research, Jakarta: Kencana, (2011), p. 35.

${ }^{4}$ Budi Agus Riswandi, Op. Cit., pp. 54-55.
} 
is a convergence of telecommunications, media and information technology. The internet has influenced the conventional legal design, one of which is Copyright law. The presence of the internet has created a new phenomenon in various aspects of human life.

Copyright law in the digital era experienced significant developments, especially regarding legal protection. Previously, the scope of Copyright protection only focused on conventional objects. However, in the digital era, the object of copyright protection has expanded, namely in the forms of creation in the form of science, art and literature that were digitized, such as the discovery of songs in MP3 format.

MP3 stands for Motion Picture Expert Group Layer 3. The development of MP3 technology began in 1987 by a research institute called Fraunhofer Institute Integrierte Schaltungen. The research on MP3 technology was given the EU EUREKA PROJECT 147 code, led by Dieter Seitzer from the University of Erlangen, Germany. In 1989, the Fraunhofer Institute of Integrierte Schaltungen obtained a patent for the MP3 technology in Germany. Then, in 1995, the Fraunhofer Institute of Integrierte Schaltungen registered an MP3 technology patent in the United States. ${ }^{5}$

MP3 technology is a software to compress digital data. The quality of compressed data has no difference with uncompressed data. That's the advantage of MP3 technology. ${ }^{6}$ The song compressed using MP3 technology comes from the original VCD. The file size of a song on an original VCD is usually around 25 Megabytes, while the file size of a song that has been compressed using MP3 technology is much smaller, which is around 2.5 Megabytes, of course with almost the same quality. After being compressed into the MP3 format, a song can be easily uploaded and distributed on internet media.

\section{Legal Protection to Copyright-Based on Law Number 28 of 2014}

Copyright is an exclusive right for the creator or the recipient of the right to announce or reproduce his work or give permission for it, by not reducing the restrictions according to the prevailing laws and regulations. ${ }^{7}$ Correspondingly, based on Article 1 of Law Number 28 of 2014 it is explained that Copyright is the creator's exclusive right that arises automatically based on declarative principles after work is realized in real form without reducing restrictions by the provisions of the legislation. ${ }^{8}$

\footnotetext{
${ }^{5}$ Ibid., p. 153.

${ }^{6}$ Ibid., p. 155.

${ }^{7}$ Eddy Damian, Copyright Law, Bandung: Alumni, (2003), p. 118.

${ }^{8}$ Law Number 28 on 2014 of Copyright (State Gazette Number 266 of 2014, Supplement to the State Gazette Number 5599).
} 
Article 40 of Law Number 28 of 2014 states that protected works include works in the fields of science, art, and literature, which consist of:

a. Books, pamphlets, displays of published papers and all other written works.

b. Lectures, speeches, and other similar works.

c. Props made for the benefit of education and science.

d. Songs and music with or without text.

e. Drama, musical drama, dance, choreography, wayang, and pantomime.

f. Works of art in all forms such as painting, drawing, carving, calligraphy, sculpture, sculpture or college.

g. Works of applied art.

h. Architectural work.

i. Map.

j. Batik artwork or other motif art.

k. Photographic works.

1. Portrait.

m. Cinematographic works.

n. Translation, interpretation, adaptation, anthology, database, arrangement, modification and other works of transformation results.

o. Translation, adaptation, arrangement, transformation or modification of traditional cultural expressions.

p. Compilation of creation or data, both in a format that can be read with computer programs and other media.

q. Compilation of traditional cultural expressions as long as the compilation is an original work.

r. Video games.

s. Computer program. ${ }^{9}$

\section{Economic Rights and Moral Rights in Copyright}

Copyright consists of economic rights and moral rights. Economic rights are the right to obtain economic benefits from creation and related rights products. The creator or holder of the Copyright has the economic right to publish the work; duplication of creation in all its forms; translation of creation; adaptation, arrangement, or transformation of creation; distribution of works or copies thereof; show creation; announcement of creation; communication creation; and creation of creations. ${ }^{10}$

Meanwhile, moral rights are rights inherent in the creator or perpetrator who can't be removed or deleted without any reason, even though the

\footnotetext{
${ }^{9}$ Law Number 28 on 2014 of Copyright (State Gazette Number 266 of 2014, Supplement to the State Gazette Number 5599).

${ }^{10}$ Law Number 28 on 2014 of Copyright (State Gazette Number 266 of 2014, Supplement to the State Gazette Number 5599).
} 
Copyright or related rights have been transferred. Moral rights are rights that are eternally attached to the creator to keep mentioning or not including his name on the copy in connection with the use of his work for the public; use their alias or disguise; changing his creation according to propriety in society; change the title and child of the title of the creation; and maintain its rights in the event of a distortion of creation, mutilation of creation, modification or creation or things that are detrimental to their self-respect or reputation. ${ }^{11}$

Law Number 28 of 2014 also regulates acts that are not considered as Copyright violations. These actions are as follows:

a. Announcement, distribution, communication, and duplication of state symbols and national anthem according to their original nature.

b. The announcement, distribution, communication and duplication of everything that is carried out by or on behalf of the government, unless otherwise protected by legislation, statements on the work or when the work is made an announcement, distribution, communication, and multiplication.

c. The actual news retrieval, both in whole and in part from news agencies, broadcasting institutions, and newspapers or other similar sources provided that the source must be stated in full.

d. Creation and dissemination of Copyright content through information and communication technology media that are non-commercial and/or beneficial to the creator or related parties or the creator states that he doesn't object to the creation and dissemination.

e. Duplication, announcement and/or distribution of portraits of the president, vice president, former president, former vice president, national heroes, heads of state institutions, leaders of ministries / nonministerial government agencies and/or regional heads with due regard for dignity and fairness by the provisions of the legislation. ${ }^{12}$

Also, actions which are also not considered as Copyright infringement are the use, retrieval, duplication and/or alteration of work and/or product related rights in whole or in the part which is substantially not considered a Copyright violation if the source is mentioned or included in full for:

a. Education, research, writing scientific papers, preparing reports, writing critics or reviewing a problem without harming the reasonable interests of the creator or copyright holder.

b. Security and administration of government, legislative and judicial bodies.

c. Lectures that are only for educational and scientific purposes.

\footnotetext{
${ }^{11}$ Law Number 28 on 2014 of Copyright (State Gazette Number 266 of 2014, Supplement to the State Gazette Number 5599).

${ }^{12}$ Law Number 28 on 2014 of Copyright (State Gazette Number 266 of 2014, Supplement to the State Gazette Number 5599).
} 
d. Performances that are free of charge provided that they don't harm the reasonable interests of the creator. ${ }^{13}$

\section{Prevention of Copyright Infringement}

Some cases of Copyright violations that have occurred before include the following:

a. A British music group called Oasis demanded that hundreds of sites on the internet media without permission have video clips of their songs accompanied by the lyrics.

b. The Australian Mechanical Copyright Owners Society (AMCOS) and The Australian Music Publishers Association Ltd stopped a site on internet media that without permission has a list of 40 popular songs since 1989.

c. Wixen Music Publishing demanded that a digital music company from Sweden named Spotify without permission have aired famous songs by Tom Petty, Neil Young, and The Doors.

Article 54 of Law Number 28 of 2014 states that to prevent Copyright infringement through information technology-based facilities, the government has the authority to:

a. Supervision of the creation and dissemination of the content of Copyright infringement.

b. Cooperation and coordination with various parties, both domestic and foreign, in preventing the creation and dissemination of the content of Copyright infringement.

c. Supervision of recording actions using any media on the work at the venue. $^{14}$

\section{Criminal Sanctions to Copyright Infringement Based on Law Number 28 on 2014}

According to Soerjono Soekanto, five factors influence law enforcement. The five factors are closely related because it is the essence of law enforcement and is a benchmark for the effectiveness of law enforcement. Factors affecting law enforcement are as follows:

a. The legal factor itself (law).

b. Factors of law enforcement.

c. Factors that support law enforcement facilities.

d. Community factors.

\footnotetext{
${ }^{13}$ Law Number 28 on 2014 of Copyright (State Gazette Number 266 of 2014, Supplement to the State Gazette Number 5599).

${ }^{14}$ Law Number 28 on 2014 of Copyright (State Gazette Number 266 of 2014, Supplement to the State Gazette Number 5599).
} 


\section{e. Cultural factors. ${ }^{15}$}

The enactment of Law Number 28 of 2014 replacing Law Number 19 of 2002 further strengthens the legal basis for regulation regarding Copyright in Indonesia.

In Article 113 of Law Number 28 of 2014 it is affirmed that every person who with no rights and / or without the permission of the creator of the copyright holder violates the economic rights of the creator in the form of publishing a work, duplicating the work in all its forms, distribution of works or copies, or announcement of creation for commercial use, shall be punished with a maximum imprisonment of 4 (four) years and / or a fine of $\mathrm{Rp}$ $1,000,000,000$ (one billion rupiah). ${ }^{16}$

In Article 113 of Law Number 28 of 2014, it is also stated that every person who fulfills the element of copying and/or commercial use of a work carried out in the form of piracy, shall be sentenced to a maximum of 10 (ten) years of imprisonment and/or the finest. a lot of $\operatorname{Rp~4,000,000,000~(four~billion~}$ rupiah). ${ }^{17}$

In addition, Article 114 of Law Number 28 of 2014 stipulates that everyone who manages a trading place in all its forms who knowingly and knowingly allows the sale and / or duplication of goods resulting from copyright infringement at the place of trade that he manages, convicted of a fine at most $\mathrm{Rp} 100,000,000$ (one hundred million rupiahs). ${ }^{18}$

When discussing the application of sanctions, it will automatically intersect with law enforcement. In general, law enforcement can be interpreted as an act of applying certain legal instruments to impose legal sanctions to guarantee compliance with the stipulated provisions. Satjipto Rahardjo explained that law enforcement is a process to realize legal desires (i.e., the thoughts of the legislature that are formulated in legal regulations) into reality. ${ }^{19}$

\section{Conclusion}

Copyright is the creator's exclusive right that arises automatically based on declarative principles after a work has been realized in real form without reducing restrictions by the provisions of the legislation. Initially, the scope of Copyright protection only focuses on creative works that are manifested in

\footnotetext{
${ }^{15}$ Soerjono Soekanto, Factors Affecting Law Enforcement, Jakarta: Rajawali Pers, (2013), pp. 8-9.

${ }^{16}$ Law Number 28 on 2014 of Copyright (State Gazette Number 266 of 2014, Supplement to the State Gazette Number 5599).

${ }^{17}$ Law Number 28 on 2014 of Copyright (State Gazette Number 266 of 2014, Supplement to the State Gazette Number 5599).

${ }^{18}$ Law Number 28 on 2014 of Copyright (State Gazette Number 266 of 2014, Supplement to the State Gazette Number 5599).

${ }^{19}$ Satjipto Rahardjo, Law Enforcement Issues, Bandung: Sinar Baru, (1983), p. 24.
} 
real terms. The development and advancement of technology make the scope of Copyright protection experience an expansion not only in copyrighted works that are realized in a real form, but also protect copyrighted works that are digitized on the internet media. In addition, technological developments and advances can also facilitate the dissemination of songs in MP3 format uploaded on the internet media. To prevent the occurrence Copyright infringement of songs on internet media, in Law Number 28 of 2014 it has been stipulated that strict criminal sanctions for anyone without permission has violated the Copyright, especially the economic rights of the owner.

\section{A. Book}

\section{Bibliography}

Damian, Eddy. (2003). Copyright Law. Bandung: Alumni.

Djaja, Ermansyah. (2009). Intellectual Property Rights Law. Jakarta: Sinar Grafika.

Margono, Suyud. (2010). Indonesian Copyright Law. Bogor: Ghalia Indonesia.

Marzuki, Peter Mahmud. (2011). Legal Research. Jakarta: Kencana.

Rahardjo, Satjipto. (1983). Law Enforcement Issues. Bandung: Sinar Baru.

Riswandi, Budi Agus. (2009). Copyright on the Internet; Legal Aspects and Problems in Indonesia. Yogyakarta: FH UII Press.

Saidin, OK. (2016). History and Political Law of Copyright. Jakarta: Rajawali Pers.

Soekanto, Soerjono. (2007). Introduction to Legal Research. Jakarta: UI Press.

Soekanto, Soerjono. (2013). Factors Affecting Law Enforcement. Jakarta: Rajawali Pers.

Sutedi, Adrian. (2009). Intellectual Property Rights. Jakarta: Sinar Grafika.

\section{B. Legislation}

Law Number 28 on 2014 of Copyright. 